\title{
Growth Performance of Philippine Native Chicken Fed Diet Supplemented with Varying Levels of Madre de Agua (Trichanthera gigantea Nees) Leaf Meal
}

\author{
Clarita E. Morbos ${ }^{1}$, Dinah M. Espina ${ }^{2}$ and Lolito C. Bestil ${ }^{2}$ \\ ${ }^{1}$ Department of Agriculture, College of Agriculture and Allied Sciences, Eastern \\ Samar State University, Salcedo, Eastern Samar, Philippines; ${ }^{2}$ Department of \\ Animal Science, Visayas State University, Baybay City, Leyte, Philippines
}

\section{ABSTRACT}

This study aimed to assess the effects of different levels of Trichanthera gigantea leaf meal (TGLM) supplementation on the growth performance of Philippine Native chickens fed commercial chicken grower ration. A total of 96 three-month old native chickens of two sexes were randomly distributed to the four treatments with 3 replicates and 4 chickens per replicate in a 2 x 4 factorial in Completely Randomized Design (CRD). Under semi-confinement system, the dietary treatments consisted of $0,5,10$, and 15\% levels of TGLM supplementation for 13 weeks. Results revealed that cumulative voluntary feed intake (VFI) increased as TGLM supplementation increased, and was significantly highest with 15\% level at weeks 10, 11 and 12. Although differences were not significant except at weeks 4 and 7 , there was a decreasing trend in cumulative weight gain (CWG) with increasing TGLM level. Average daily gain (ADG) was not significantly affected by varying levels of TGLM supplementation, and feed conversion efficiency (FCE) showed a decreasing trend as TGLM level increased and was only significantly low $(p<0.01)$ with 15\% level at week 7 . Comparing between sexes, the males were significantly higher than females in all production performance parameters. Therefore, TGLM is palatable but not adequate enough to supply the nutrients needed for a comparable weight gain with that of $0 \%$ supplementation, and a 5 $10 \%$ inclusion in the diet is recommended.

Keywords: Growth, forage leafmeal, native chicken, supplementation

\section{INTRODUCTION}

Native chicken production plays an important socio-economic role in developing countries as they remain to be the most dominant avian species raised despite the introduction of exotic strains (FAO, 2004). They are important source of animal protein and are normally reared by smallholder farmers with meager resources because they are hardy, adapt well to rural environments, survive on little inputs, and adjust to fluctuations in feed availability (Goromela et al., 2008). They are usually reared under free range (Mekria and Gezahegn, 2010) or extensive 
use. Hence, it becomes imperative among smallholder farmers to adopt a feeding strategy that is convenient and less expensive for their free-ranging native chicken. With the current interest of poultry consumers on organic animal products, attention is now directed on the use of plant forages as supplement to scavenging poultry (Branckaert and Gueye, 1999). With great potential is the leaf meal of Trichanthera gigantea or "madre de agua". It is a non-legume species which adapts well to humid-tropical conditions that is well-accepted by a range of domestic animals after a period of familiarization (Rosales, 1997). It is known to contain soluble carbohydrates, with protein ranging from 17 to $22 \%$ on DM basis, most of which are true protein with good amino acid balance (Rosales, 1997; Hess and Dominguez, 1998). The plant contains low level of anti-nutritional factors (Rosales, 1997) and the leaves are highly palatable to animals. However, there is a dearth of information on the level of supplementation in native chickens, hence, this study.

This study aimed to assess the potential of Trichanthera gigantea leaf meal on promoting growth of native chickens, and determine the optimum level of Trichanthera gigantea leaf meal supplementation for native chickens.

\section{MATERIALS AND METHODS}

\section{Preparation of the Supplement}

The fresh mature leaves of T. gigantea were sundried to about 10-14\% moisture in elevated plastic mesh, turning the leaves occasionally for uniform dryness. The dried leaves were then hammer-milled through 2-mm sieve. After which, samples of the leaf meal and the commercial grower ration were subjected to laboratory analysis using standard methods (AOAC, 1995).

\section{Care and Management of ExperimentalBirds}

A total of 96 three-month old native chickens were used. A one-week period was observed for adaptation to the new environment, and the recommended management practices were properly implemented to all experimental birds. The experimental site was properly lighted at night to stimulate feed consumption, and fenced to prevent predation and entry of non-experimental animals and persons.

Upon arrival of the birds, commercial grower ration was given ad libitum for two weeks. On the third week, the birds were gradually shifted to the dietary treatments fed twice daily at 7:00 AM and 4:00 PM at $90 \mathrm{~g}$ per bird/day with access to fresh and clean drinking water. Proper health program and sanitation practices, including bio-security measures for the experimental birds were strictly implemented by a field veterinarian.

\section{ExperimentalTreatments and Design}

Ninety-six birds, 48 males and 48 females, were randomly distributed to the different treatments. The 24 cages were designed to have a loafing area and equipped with water and feed troughs. The Trichanthera gigantea leaf meal (TGLM) was mixed with the commercial grower ration in the following levels: $T_{0}=0 \%$ 
(control); $\mathrm{T}_{1}=5 \% ; \mathrm{T}_{2}=10 \%$; and $\mathrm{T}_{3}=15 \%$, replicated 3 times, and the experiment was laid out in $2 \times 4$ factorial in completely randomized design (CRD).

\section{Data Gathered and Analysis}

1. Cumulative Voluntary Feed Intake (CVFI) - This was calculated as:

$$
\text { CVFI, } g=\frac{\text { Total Feed Given - Feed Refused }}{\text { Number of Birds }}
$$

2. Cumulative Weight Gain (CWG) - the CWG of the birds was calculated as:

$$
\text { CWG, } g=B W i-B W o
$$

where: $\quad$ BWi = body weight of birds at ith period of measurement $\mathrm{BWo}=$ initial body weight

3. Average Daily Gain (ADG), g-This was computed using the formula:

$$
\mathrm{ADG}=\frac{\text { Final live weight }- \text { Initial Weight }}{\text { Feeding days }}
$$

4. Feed Conversion Efficiency (FCE) - This was calculated as:

$$
\mathrm{FCE}=\frac{\mathrm{CVFI}}{\text { BWi }-\mathrm{BWO}}
$$

where: CVFI = the cumulative voluntary feed intake of birds $\mathrm{BWi}=$ body weight of ith period of measurement $\mathrm{BWo}=$ initial body weight

Data collected were subjected to one-way ANOVA using SPSS version 17. Post hoc analysis using DMRT was employed to compare treatment means.

\section{RESULTS AND DISCUSSION}

\section{Cumulative Voluntary Feed Intake}

As presented in Table 1 and Figure 1, there were no significant differences in the voluntary feed intake among treatments observed, except in the later stages of the growing period (at weeks 10,11, and 12), showing highest intake levels in T3 group (15\% TGLM) and lowest in T0 (control, without TGLM). This result showed that TGLM is palatable, and increasing levels did cause reduction in voluntary intake. This is supported by Rosales (1997), saying that Trichanthera gigantea forage is highly palatable to animals. It could also be due to its bulky character with rather lower nutrient concentration per unit weight, thus birds eat more to satisfy their needs (Adeyemi, et al., 2012).

Nutrient requirements of chickens were also influenced by genotype and body size. In terms of sex, male chickens showed significantly higher voluntary feed intake compared to females throughout the growing period (Table 1 and Figure 2). 
The higher intake levels of male birds could be attributed to their large body size and superior muscling, and large-sized birds tend to require more dietary nutrients than their small- sized counterparts (Magala et al., 2012).

\section{Cumulative Weight Gain}

The cumulative weekly weight gain (CWG) of the birds revealed no significant effects of the varying levels of TGLM supplementation except in weeks 4 and 7 (Table 2 and Figure 3). However, the pattern of differences showed a generally decreasing trend in CWG with increasing level of TGLM supplementation. Growing birds have a definite limit for protein accretion, and this ability is mainly governed by genotype (Legates and Everett, 1990; Samadi, 2006). Acar et al. (1993) observed that slow-growing chicken strains have lower muscular DNA concentration than their fast- growing counterparts, which explains the slowresponse of native chicken genotype. It appeared that nutrient density of TGLM is incomparable to the commercial grower ration even with increasing VFI as TGLM level increases. Looking at differences between male and female birds, Table 2 and Figure 4 showed significantly higher $(\mathrm{P}>0.01) \mathrm{CWG}$ of males than females which could be attributed to sexual dimorphism that resulted to male chickens growing faster than females and as a consequence of their higher voluntary intake levels.

Table 1. Cumulative voluntary feed intake (g) of male and female native chickens fed diet supplemented with varying levels of T. gigantea leaf meal.

\begin{tabular}{crrrrrrrrrrrrrr}
\hline \multirow{2}{*}{ Sex } & \multicolumn{10}{c}{ Week } \\
\cline { 2 - 13 } & 1 & 2 & 3 & 4 & 5 & 6 & 7 & 8 & 9 & 10 & 11 & 12 & 13 \\
\hline $\mathrm{F}$ & $428^{\mathrm{b}}$ & $380^{\mathrm{b}}$ & $399^{\mathrm{b}}$ & $432^{\mathrm{b}}$ & $432^{\mathrm{b}}$ & $404^{\mathrm{b}}$ & $418^{\mathrm{b}}$ & 480 & 479 & $489^{\mathrm{b}}$ & $519^{\mathrm{b}}$ & $520^{\mathrm{b}}$ & $507^{\mathrm{b}}$ \\
$\mathrm{M}$ & $472^{\mathrm{a}}$ & $444^{\mathrm{a}}$ & $468^{\mathrm{a}}$ & $499^{\mathrm{a}}$ & $553^{\mathrm{a}}$ & $517^{\mathrm{a}}$ & $489^{\mathrm{a}}$ & 517 & 516 & $551^{\mathrm{a}}$ & $554^{\mathrm{a}}$ & $571^{\mathrm{a}}$ & $593^{\mathrm{a}}$ \\
p-value & 0.017 & 0.035 & 0.006 & 0.006 & 0.000 & 0.001 & 0.027 & 0.228 & 0.152 & 0.005 & 0.019 & 0.001 & 0.000 \\
Treatments & & & & & & & & & & & & & \\
$\mathrm{T}_{0-} \%$ & 482 & 394 & 437 & 429 & 457 & 428 & 405 & 445 & 462 & $469^{\mathrm{b}}$ & $501^{\mathrm{b}}$ & $504^{\mathrm{b}}$ & 515 \\
$\mathrm{~T}_{1}-5 \%$ & 452 & 437 & 446 & 458 & 475 & 456 & 439 & 505 & 497 & $506^{\mathrm{ab}}$ & $529^{\mathrm{ab}}$ & $546^{\mathrm{ab}}$ & 552 \\
$\mathrm{~T}_{2-1} 10 \%$ & 428 & 406 & 434 & 510 & 550 & 489 & 477 & 507 & 494 & $533^{\mathrm{ab}}$ & $557^{\mathrm{a}}$ & $554^{\mathrm{ab}}$ & 547 \\
$\mathrm{~T}_{3-1} 15 \%$ & 437 & 410 & 416 & 465 & 487 & 470 & 493 & 537 & 536 & $574^{\mathrm{a}}$ & $558^{\mathrm{a}}$ & $579^{\mathrm{a}}$ & 588 \\
p-value & 0.156 & 0.748 & 0.801 & 0.099 & 0.061 & 0.437 & 0.183 & 0.215 & 0.239 & 0.011 & 0.022 & 0.005 & 0.074 \\
\hline
\end{tabular}

Column means with no common letter-superscript are significantly different.

\section{Average Daily Gain}

The average daily gain (ADG) was not significantly affected by the different levels of TGLM, showing a similar pattern of differences than that of the CWG (Table 3 and Figure 5). However, the results suggested that up to 10\% TGLM level of incorporation could be better than higher levels. Comparing between sexes, ADG was significantly greater $(\mathrm{P}<0.01)$ in males than in females, due to sexual dimorphism and as a consequence of higher voluntary feed intake. This finding is supported by Ndegwa et al. (2012) who said that cockerels generally grow faster than pullets and show a better response to high dietary protein levels. 


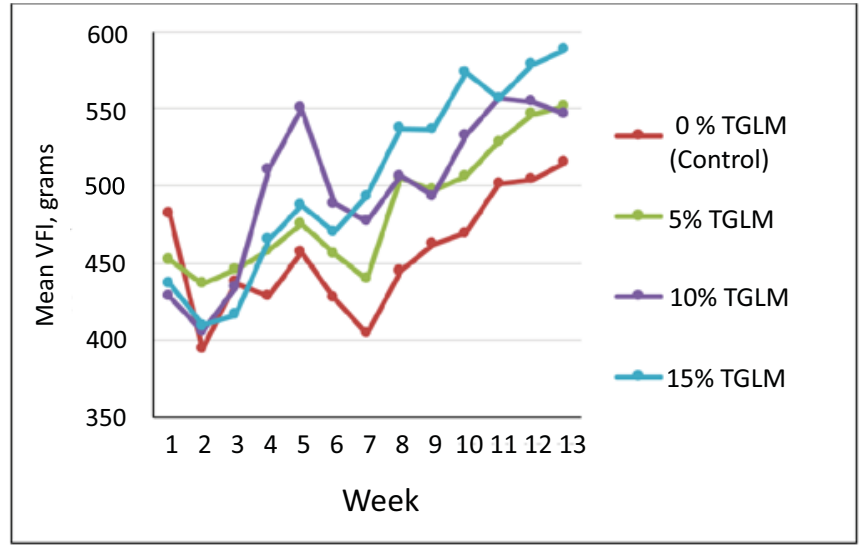

Figure 1. Cumulative voluntary feed intake (g) of native chicken varying levels of T. gigantea leaf meal across sexes.

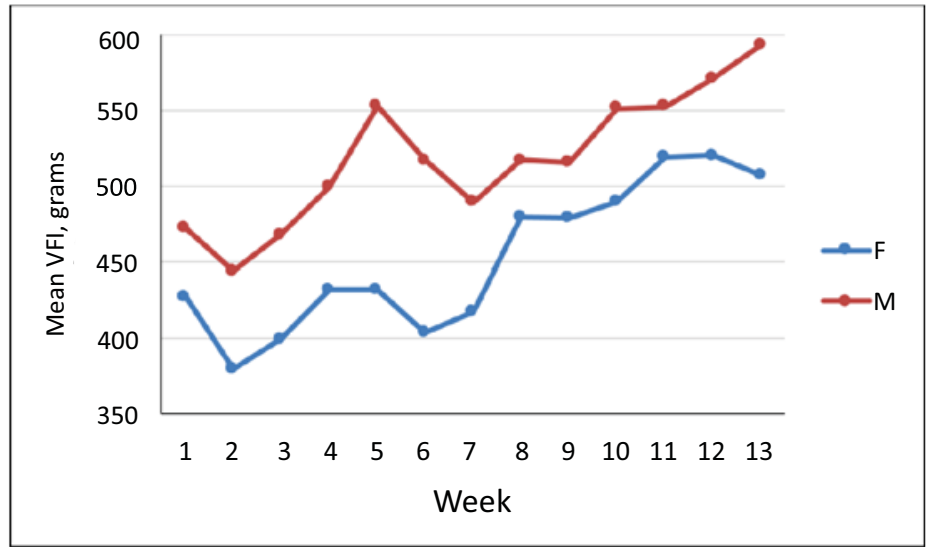

Figure 2. Cumulative voluntary feed intake (g) of female and male native chicken across levels of T. gigantea leaf meal supplementation.

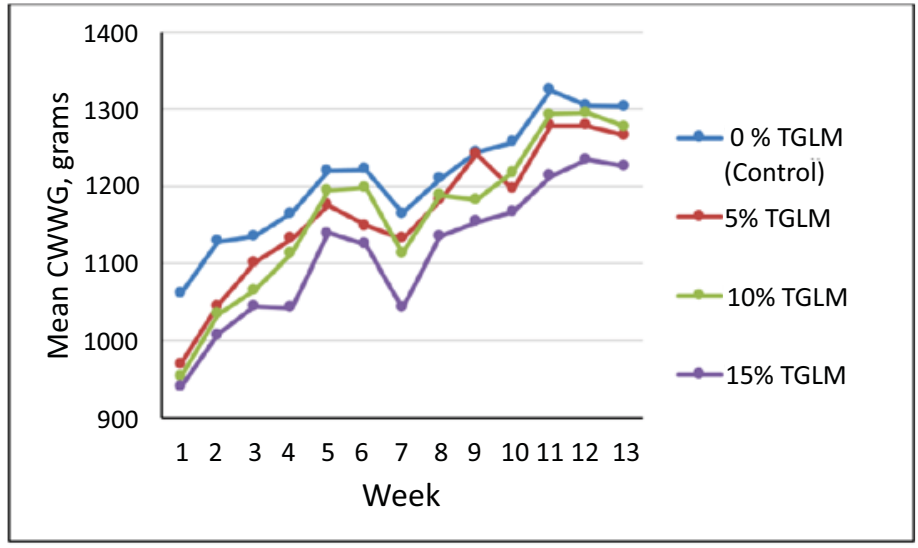

Figure 3. Cumulative weekly weight gain $(\mathrm{g})$ of native chickens fed diets supplemented with Trichantheragigantealeaf meal across sexes. 


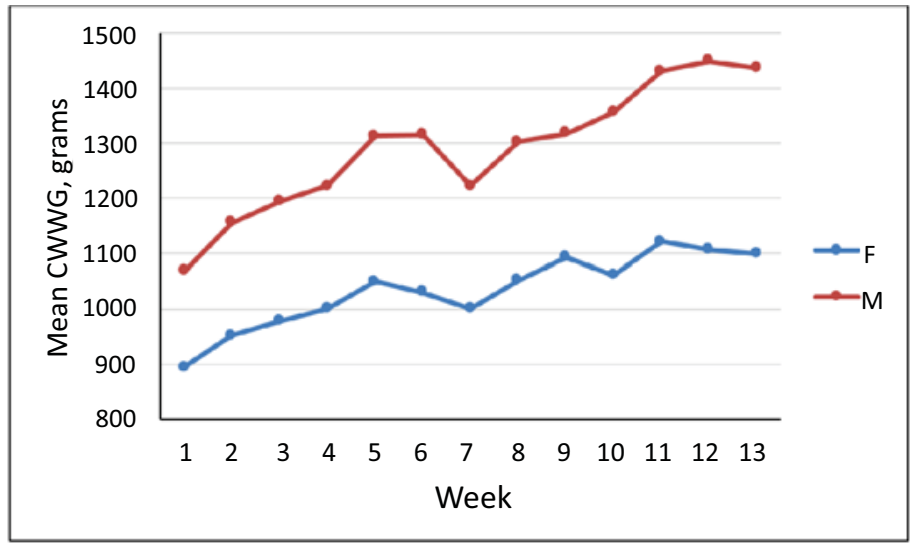

Figure 4. Cumulative weekly weight gain (g) of female and male native chickens across different levels of Trichanthera gigantea leaf meal supplementation.

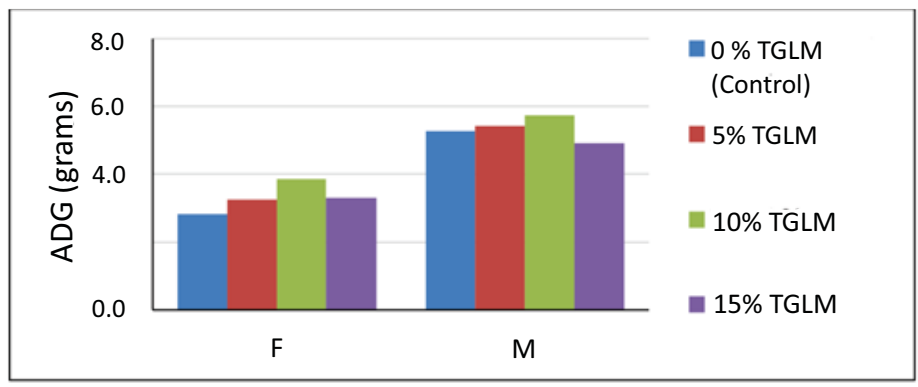

Figure 5. Average daily gain (g) of male and female native chickens fed diet supplemented with varying levels of $T$. gigantealeaf meal.

Table 2. Cumulative weight gain (g) of male and female native chickens fed diet supplemented with varying levels of $T$. gigantea leaf meal.

\begin{tabular}{|c|c|c|c|c|c|c|c|c|c|c|c|c|c|}
\hline \multirow{2}{*}{ Sex } & \multicolumn{13}{|c|}{ Week } \\
\hline & 1 & 2 & 3 & 4 & 5 & 6 & 7 & 8 & 9 & 10 & 11 & 12 & 13 \\
\hline F & $895^{\mathrm{b}}$ & $952^{\mathrm{b}}$ & $978^{\mathrm{b}}$ & $1001^{b}$ & $1051^{\mathrm{b}}$ & $1030^{\mathrm{b}}$ & $1001^{b}$ & $1053^{b}$ & $1093^{b}$ & $1062^{\mathrm{b}}$ & $1122^{b}$ & $1106^{\mathbf{b}}$ & $1099 \mathrm{~b}$ \\
\hline M & $1068^{a}$ & $1156^{a}$ & $1194^{a}$ & $1224^{a}$ & $1313^{a}$ & $1316^{a}$ & $1224^{a}$ & $1303^{a}$ & $1317^{a}$ & $1356^{\mathrm{a}}$ & $1431^{a}$ & $1449^{a}$ & $1437^{a}$ \\
\hline p-value & 0.000 & 0.000 & 0.000 & 0.000 & 0.000 & 0.000 & 0.000 & 0.000 & 0.000 & 0.000 & 0.000 & 0.000 & 0.000 \\
\hline \multicolumn{14}{|c|}{ Treatments } \\
\hline $0 \%$ & 1061 & 1128 & 1134 & $1165^{\mathrm{a}}$ & 1220 & 1221 & $1165^{a}$ & 1209 & 1244 & 1256 & 1323 & 1304 & 1303 \\
\hline $5 \%$ & 971 & 1046 & 1100 & $1131^{a b}$ & 1175 & 1149 & $1131^{\mathrm{ab}}$ & 1181 & 1242 & 1195 & 1278 & 1278 & 1266 \\
\hline $10 \%$ & 954 & 1034 & 1066 & $1112^{\mathrm{ab}}$ & 1194 & 1198 & $1112^{\mathrm{ab}}$ & 1188 & 1182 & 1218 & 1293 & 1295 & 1277 \\
\hline $15 \%$ & 940 & 1008 & 1045 & $1042^{\mathrm{b}}$ & 1139 & 1124 & $1042^{\mathrm{b}}$ & 1134 & 1153 & 1167 & 1212 & 1234 & 1225 \\
\hline p-value & 0.054 & 0.062 & 0.174 & 0.012 & 0.363 & 0.172 & 0.012 & 0.544 & 0.373 & 0.188 & 0.102 & 0.331 & 0.426 \\
\hline
\end{tabular}

Column means with no common letter-superscript are significantly different. 
Table 3. Average daily gain (ADG) of male and female native chickens fed diet supplemented with varying levels of $T$. gigantea leaf meal.

\begin{tabular}{|c|c|c|}
\hline Factors & & ADG $(g)$ \\
\hline \multirow{3}{*}{ Sex } & Female & $3^{\mathrm{b}}$ \\
\hline & Male & $5^{a}$ \\
\hline & $p$-value & 0.000 \\
\hline \multirow{5}{*}{ Treatments } & $\mathrm{T}_{0-} 0 \%$ TGLM (Control) & 4 \\
\hline & $\mathrm{T}_{1} .5 \% \mathrm{TGLM}$ & 4 \\
\hline & $\mathrm{T}_{2} .10 \% \mathrm{TGL}$ & 5 \\
\hline & $\mathrm{T}_{3}-15 \%$ TGLM & 4 \\
\hline & p-value & 0.613 \\
\hline
\end{tabular}

Column means with no common letter-superscripts within a factor are significantly different.

\section{Feed Conversion Efficiency}

Feed conversion efficiency (FCE) is "feed per gain" ratio, measured in terms of the amount of feed required to produce a unit of weight gain, so that the smaller the value the more efficient it is (Bestil, 2001). Results revealed no significant differences among treatments except in week 7 where increasing level of TGLM in the diet lowers the FCE of birds. It should be noted that as birds grow older, they become more efficient in utilizing feed containing TGLM (Table 4 and Figure 6), and males were significantly more efficient than females at weeks 10 to 13 (Table 4 and Figure 7).

Table 4. Feed conversion efficiency (FCE) of male and female native chickens fed diets supplemented with varying levels of T. gigantea leaf meal.

\begin{tabular}{|c|c|c|c|c|c|c|c|c|c|c|c|c|c|}
\hline \multirow[b]{2}{*}{ Sex } & \multicolumn{13}{|c|}{ Week } \\
\hline & 1 & 2 & 3 & 4 & 5 & 6 & 7 & 8 & 9 & 10 & 11 & 12 & 13 \\
\hline $\mathrm{F}$ & 5.13 & 2.67 & 2.36 & 2.32 & 1.76 & 2.25 & 2.29 & 2.28 & 1.79 & $2.11^{\mathrm{b}}$ & $1.73^{\mathrm{b}}$ & $1.78^{\mathrm{b}}$ & $1.80^{\mathrm{b}}$ \\
\hline M & 4.77 & 2.38 & 2.01 & 1.92 & 1.63 & 1.50 & 1.89 & 1.66 & 1.56 & $1.45^{\mathrm{a}}$ & $1.22^{\mathrm{a}}$ & $1.19^{\mathrm{a}}$ & $1.29^{\mathrm{a}}$ \\
\hline p-value & 0.653 & 0.343 & 0.109 & 0.075 & 0.432 & 0.086 & 0.032 & 0.168 & 0.369 & 0.030 & 0.012 & 0.000 & 0.009 \\
\hline \multicolumn{14}{|c|}{ Treatments } \\
\hline $0 \%$ & 4.29 & 2.40 & 2.31 & 1.96 & 1.74 & 2.01 & $1.82^{\mathrm{a}}$ & 2.05 & 1.75 & 1.86 & 1.57 & 1.56 & 1.60 \\
\hline $5 \%$ & 5.68 & 2.63 & 2.05 & 1.86 & 1.64 & 2.05 & $1.75^{\mathrm{a}}$ & 2.06 & 1.47 & 1.78 & 1.41 & 1.49 & 1.55 \\
\hline $10 \%$ & 4.34 & 2.25 & 2.09 & 2.01 & 1.64 & 1.39 & $1.86^{\mathrm{a}}$ & 1.52 & 1.52 & 1.48 & 1.31 & 1.28 & 1.35 \\
\hline $15 \%$ & 5.50 & 2.81 & 2.29 & 2.66 & 1.76 & 2.04 & $2.93^{\mathrm{b}}$ & 2.26 & 1.98 & 1.98 & 1.61 & 1.61 & 1.69 \\
\hline p-value & 0.470 & 0.566 & 0.724 & 0.060 & 0.930 & 0.614 & 0.000 & 0.657 & 0.460 & 0.628 & 0.599 & 0.324 & 0.575 \\
\hline
\end{tabular}

Column means with no common letter-superscript are significantly different.

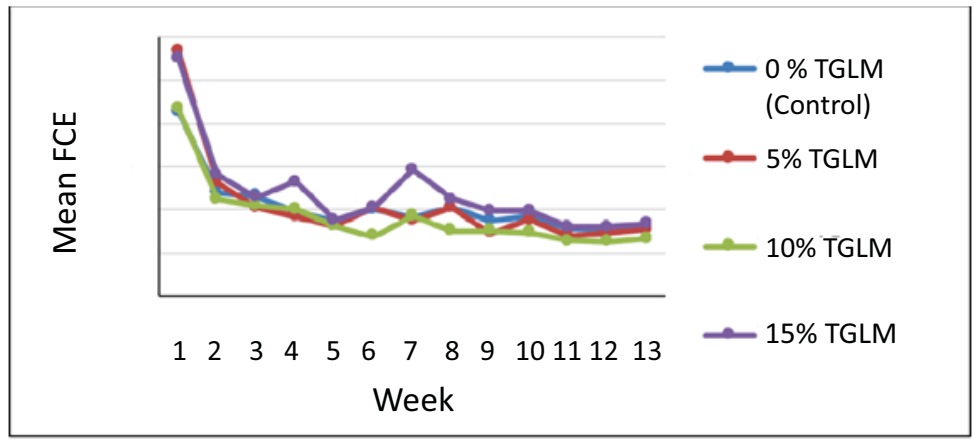

Figure 6. Feed conversion efficiency (FCE) of native chickens fed diet supplemented with varying levels of T. gigantea leaf meal across sexes. 


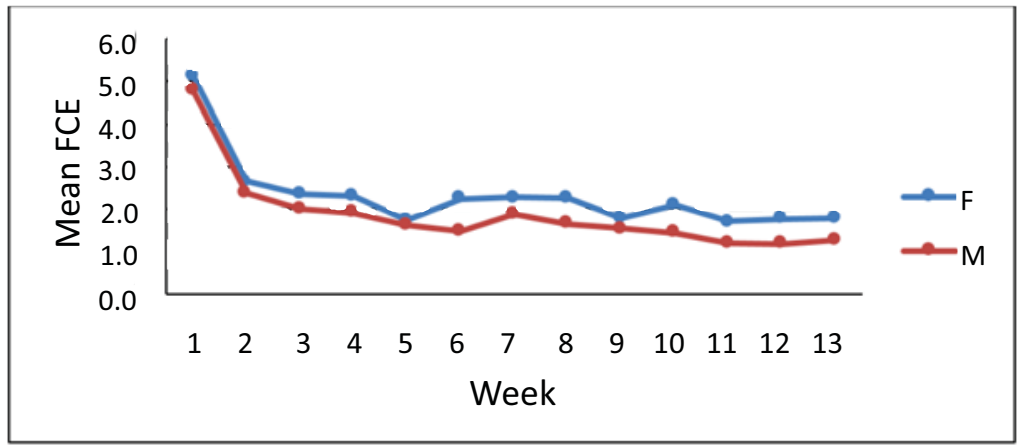

Figure 7. Feed conversion efficiency (FCE) of female and male native chicken across varying levels of T. gigantea leaf meal supplementation.

\section{CONCLUSION}

The inclusion of $T$. gigantea leaf meal in the chicken grower ration has great potential in terms of voluntary feed intake and feed conversion efficiency, and does not significantly reduce weight gain. Its nutrient density was not enough to support higher weight gains, so that levels up to $10 \%$ in the grower ration can be adopted. Thus, its inclusion in chicken grower rations could be practically adopted for a cost-effective feeding of native chickens.

\section{ACKNOWLEDGMENT}

The funding support of DOST-Accelerated Science and Technology Human Resource Development Program, and the assistance of Dr. Norberto Milla in analyzing the data, are greatly acknowledged.

\section{REFERENCES}

ACAR, N., E.T. MORAN, and D.R. MULVANEY. 1993. Breast muscle development of commercial broilers from hatchery to 12 weeks of age. Poultry Sci., 72: $317-325$.

ADEYEMI, O, A., J. A.ADEKOYA, and R. A. SOBAYO. 2012. Performance of broiler chicken fed diets containing cassava leaf-blood meal mix as replacement for soybean meal. Revista Cientifica UDO Agricola, 12 (1): 212-219.

BESTIL, L.C. 2001. Performance of broilers fed low-protein diets with lysine and methionine supplementation. Proceedings: $19^{\text {th }}$ Annual Scientific Seminar and Convention, Phil. Soc. Anim. Science - Visayas Chaper, Bohol, Phil.

BRANCKAERT, R. D. S. and E. F. GUEYE. 1999. "FAO's Programme for Support to Family Poulty Production". In the Proceedings of the Workshop on "Poultry as a Tool in Poverty Eradication and Promotion of Gender Equality."

FAO. 2004. Small Scale Poultry Production. A Corporate Document Repository. http// wmw.fao.org/ documents/ advanced-s-result.asp?

GOROMELA, E. H., R.P. KWAKKEL, M. W. A. VERSTEGEN, and A. M. KATULE 2008. Effect of Season and Farming System on the Quality and Nutritional Quality of Scavengeable Feed Resources and Performance of Village Poultry in Central Tanzania. J. Cell Anim. Biol., 2:63-71. 
HESS H. D. and DOMINGUEZ J.C. 1998. Leaves of Trichanthera gigantea as a nutritional supplement for sheep. Pasturas Tropicales. 20(3): 11-15.

LEGATES, J.E., and J.W. EVERETTE. 1990. Breeding and Improvement of Farm Animals. McGraw Hill International Editions, New York USA.

MAGALA H., D.R. KUGONZA, H. KWIZERA and C.C. KYARISIIMA. 2012. Influence of Varying Dietary Energy and Protein on Growth and Carcass Characteristics of Ugandan Local Chickens. J. Anim. Prod. Adv. 2 (7):316 -324.

MEKRIA, S. and E. GEZAHEGN. 2010. Prevalence of External Parasites of Poultry in Intensive and Backyard Chicken Farm at Wolayta Saddo town, Southern Ethiopia. Vet. World, 3:533-538.

NDEGWA, J.M., R. MEAD, P. NORRISH, C.W. KIMANI, and A.M. WACHIRA. 2001. The Growth Performance of Indigenous Kenyan Chickens Fed Diets Containing Different Levels of Protein during Rearing. Trop. Anim. Health Prod., 33: $441-448$.

ROSALES, M. 1997. Trichanthera gigantea (Humboldt and Bonpland.) Nees: A Review. Livestock Research for Rural Development, Vol.9, Number 4 http://www.cipav.org.co/lrrd/lrrd9/4/mauro942.htm.

SAMADI, LIEBERT F. 2006. Estimation of Nitrogen Maintenance Requirements and Potential for Nitrogen Deposition in Fast- Growing Chickens Depending on Age and Sex. Poultry Science, 85: 1421 -1429. 